\title{
Review of Stunting in Indonesia
}

\author{
Yuli Anggraini ${ }^{1, *}$ Nur Faizah Romadona ${ }^{1}$
}

\author{
${ }^{1}$ Department of Early Childhood Education, Universitas Pendidikan Indonesia, Bandung, Indonesia \\ *Corresponding author. Email: yuliqibut@gmail.com
}

\begin{abstract}
Failure to reach one's potential for growth - is caused by chronic malnutrition and repeated illness during childhood. It reflects the cumulative effects of chronic malnutrition during the 1,000 first days of life, and is also associated with lack of education, poverty, less healthy, and more vulnerability to noncommunicable diseases and is indicative of a poor quality of life that negatively affects the nation's human resources. Globally, Indonesia ranks fifth in terms of stunting. According to the 2014 Global Nutrition Report (based on data from 117 countries), Indonesia is one of the 17 countries with three major malnutrition problems: stunting, wasting and obesity. The 2018 National Health Research (Riskesdas), shows that $30.8 \%$ of children under five in Indonesia experience stunting, which is down when compared to the 2013 Riskesdas data, that is 37.2\%. In 2017, Indonesian Vice President Jusuf Kalla called for a National Strategy to Accelerate Stunting Prevention. The strategy, supported by the World Bank, was built on Indonesia's experience and global lessons, particularly Peru's success in cutting its stunting rate by half in just seven years.
\end{abstract}

Keywords: Stunting, malnutrition, Indonesia

\section{INTRODUCTION}

Stunting is a major cause of stunted growth in a person's height caused by malnutrition and recurrent disease during childhood. The diagnosis of stunting is determined based on World Health Organization (WHO) standard deviation (World Health Organization [WHO], 2014). Stunting itself is influenced by nutritional intake problems, hormones and infectious diseases (Harding, 2004). In addition, other factors that cause stunting are environmental influences in the form of exposure to cigarette smoke and pollution (Kyu, Georgiades, \& Boyle, 2009). Nutrition in the first 1,000 days of life is one way to prevent stunting in early childhood. The provision of balanced nutrition in the first 1,000 days of life can prevent malnutrition and infectious diseases (Aryastami \& Tarigan, 2017). In addition, the fulfillment of nutrition in the first 1,000 days of life can affect cognitive life at a later age (Black et al., 2008). The low nutritional supply in the first 1,000 days of a child's life, will have a long-term impact, namely to the age of puberty (Aryastami, 2015).

In Indonesia, based on the results of Riskesdas in 2013, the magnitude of the Stunting problem was relatively stagnant at around $37 \%$ from 2007 to 2013 . Of the 33 provinces in Indonesia, more than half had a prevalence rate above the national average. While the prevalence of LBW according to Riskesdas $11.1 \%$ (2010) and $10.2 \%$ (2013); The proportion of exclusive breastfeeding for 6 months is still low $(15.3 \%)$. One reason is because there is a significant relationship between body weight at birth and less optimal breastfeeding and MPASI in the first 1000 days of life (Kanoa, Zabut, Hamed, 2011).

\section{STUNTING FACTORS AND EFFECTS}

Nutritional problems are the problems in the life cycle, starting from the time of pregnancy, babies, toddlers, teens, up to seniors. Nutritional problems can occur in all age groups, even nutritional problems at a particular age group will affect the nutritional status in the next life cycle period (intergenerational impact) (Republik Indonesia, 2012). The impact of malnutrition begins with a slowdown or retardation of fetal growth known as IUGR (Intra-Uterine Growth Retardation). The main factors that cause IUGR are the poor nutritional status of the mother at the time of conception, low body weight growth due to insufficient food content, and short maternal height due to childhood malnutrition and / or frequent infections (Simbolon, 2012). If there is no handling of the IUGR it will continue in the next generation so that there will be problems with intergenerational short children (Republik Indonesia, 2013). Food substances, growth substances and vitamins in the mother and health status is very important as a determinant of stunting. A mother who lacks nutrients, growth substances and vitamins are more likely to have stunted children and economic problems (United Nations Children's Fund [UNICEF], 2013). Fulfillment of adequate nutrients, both macro and micro nutrients is needed to avoid or reduce the risk of stunting. The quality and quantity of good MPASI is an important component in food because it contains sources of macro and micro nutrients that play a role in 
linear growth. Giving foods that are high in protein, calcium, vitamin A, and zinc can stimulate a child's height. The provision of adequate nutrition affects the normal growth pattern so that it can catch up (Rahayu, 2011). The arrangement and quality of food provided to infants is very dependent on mother's education and knowledge and the availability of food at the household level. Mother's awareness of good nutrition given to children plays an important role in maintaining the quality of food provided. Research shows that the higher the education of mothers is followed by the easier access of mothers to obtain information about nutrition and health, so that it is positively related to the increase in toddler energy consumption. This condition also explains the importance of mother's education for the nutritional quality of children. (Riyadi, Martianto, Hastuti, Damayanthi, \& Murtilaksono, 2011). Research in East Nusa Tenggara shows that the role of mothers as "gate keepers" in maintaining household consumption and nutritional status is very prominent. The role can be seen from the influence of maternal nutrition knowledge, access to nutrition and health information, nutrition practices and maternal health and allocation of food and non-food expenditure (income) (Picauly \& Magdalena, 2013). Research in Ethiopia identified factors associated with high stunting in breast-fed infants. The results show that babies from mothers who have low zinc concentrations in breast milk are more stunting (Assefa, Belachew, \& Negash, 2013). Another major factor related to the occurrence of stunting is the socioeconomic factor. Economic social status, age, sex and mother's education are important factors of adolescent nutritional status (underweight and stunting) (Assefa et al., 2013). Research conducted in middle and low income countries shows that children who live in slums, as children age, the risk of stunting worsens (Kyu \& Shannon, 2013). Children's health is also a determining factor for stunting. Repeated or prolonged episodes of diarrhea during childhood increase the risk of stunting (Ricci et al., 2006).

\section{THE PREVALENCE OF STUNTING IN INDONESIA}

Based on the results of Basic Health Research (Badan Penelitian dan Pengembangan Kementerian Kesehatan RI, 2013) it has been shown that an increase in stravel pravelansi in 2015 amounted to $29.0 \%$, but in 2016 it has decreased by $1.5 \%$ in 2016 with a total of $27.5 \%$. Then, in 2018 the prevalanet stunting rate had increased quite high reaching 30.8. For the increase in the level of stunting prevalence in the toddler age group in Indonesia which has become the government's attention, which then made efforts to reduce the level of stunting in Indonesia (Riskesdas, 2018)

\section{STUNTING COUNTER MEASURES POLICY}

The foundation for a long-term policy on food and nutrition programs was formulated in Law No.17 of 2007 concerning the National Long-Term Development Plan (RPJPN) 2005-2025. A multi-sector approach to food and nutrition development includes production, processing, distribution, and food consumption, with adequate, balanced nutritional content and guaranteed safety. Longterm development is executed gradually in the period of five years, formulated in the document of the National Medium Term Development Plan (RPJMN) stipulated in Presidential Regulation. In the second phase of RPJMN for the period 2010-2014, there were two outcome indicators related to nutrition, namely the prevalence of malnutrition (malnutrition and malnutrition) of $<15$ percent and the prevalence of stunting (short) by 32 percent at the end of 2014. Program objectives nutrition is more focused on pregnant women to children aged 2 years (Republik Indonesia, 2012). The focus of the nutrition improvement movement is on the first 1000 days of life, on a global level called the Scaling Up Nutrition (SUN) and in Indonesia the National Nutrition Awareness Movement in the Framework of Accelerating Nutrition Improvement in the First 1000 Days of Life (First 1000 Days of Life Movement and abbreviated 1000 HPK Movement). SUN movement is a global effort from various countries in order to strengthen commitments and action plans to accelerate nutrition improvement, especially nutrition management since 1,000 days from pregnancy to children aged 2 years. This movement is a response from countries in the world to the nutritional status in most developing countries and the result of uneven progress in achieving the Millennium Development Goals (Goal 1) (Republik Indonesia, 2012). The SUN Movement is a new effort to eliminate malnutrition in all its forms. The principle of this movement is that everyone has the right to good food and nutrition. This is unique because it involves a variety of different community groups including government, private sector, NGOs, scientists, civil society and the United Nations jointly taking collective action to improve nutrition. Interventions conducted on SUN are specific and sensitive interventions (Scaling Up Nutrition, 2013). Specific interventions are actions or activities planned specifically for the first 1000 days of life (HPK) and are short-term in nature. This activity is generally carried out in the health sector, such as immunization, PMT for pregnant women and children under five, monitoring the growth of children under five in the Posyandu, supplementing iron-folate tablets for pregnant women, promoting exclusive breastfeeding, MP-ASI, and so on. Whereas sensitive interventions are various development activities outside the health sector aimed at the general public. Some of these activities are the provision of clean water, sanitation 
facilities, various poverty reduction, food security and nutrition, food fortification, education and IEC Nutrition, education and IEC Health, gender equality, and others (Republik Indonesia, 2013). At the beginning of 2013, there were 33 SUN countries for 59 million stunting children representing about one third of all stunting children in the world. The average annual rate of stunting reduction in 33 countries is $1.8 \%$. WHO recommends stunting reduction of $3.9 \%$ per year in order to meet the global target of stunting reduction in 2025 by $40 \%$ (Scaling Up Nutrition, 2013).

\section{CONCLUSIONS}

The problem of stunting is a nutritional problem facing the world, especially poor and developing countries. Stunting is a growth failure due to accumulation of nutrient insufficiency that lasts long from pregnancy to the age of 24 months. Many factors cause the high incidence of stunting in infants. Society has not yet realized stunting as a problem compared to other malnutrition problems. Globally, policies aimed at reducing the incidence of stunting are focused on the first 1000 days, known as Scaling Up Nutrition. WHO recommends stunting to decrease by $3.9 \%$ per year in order to meet the target of a $40 \%$ reduction in stunting by 2025 . Interventions are carried out throughout the life cycle in both the health and non-health sectors involving various walks of life such as government, private sector, civil society, the United Nations through collective action to improve nutritional improvement, both short term (specific interventions) and long term (sensitive).

\section{REFERENCES}

Aryastami, N. K. (2015). Pertumbuhan usia dini menentukan pertumbuhan usia pra-pubertas (Studilongitudinal IFLS 1993-1997-2000) (Doctoral Thesis). Retrieved from http://lib.ui.ac.id/detail?id=20404525\&lokasi=lokal.

Aryastami, N. K., \& Tarigan, I. (2017). Policy analysis on stunting prevention in indonesia. Buletin Penelitian Kesehatan, 45(4), 233-240.

Assefa, H., Belachew, T., \& Negash, L. (2013). Socioeconomic factors associated with underweight and stunting among adolescents of Jimma Zone, South West Ethiopia: A cross-sectional study. ISRN Public Health, 2013.

Badan Penelitian dan Pengembangan Kementerian Kesehatan RI. (2013). Laporan riset kesehatan dasar 2013. Jakarta: Badan Penelitian dan Pengembangan Kementerian Kesehatan RI.
Black, R. E., Allen, L. H., Bhutta, Z. A., Caulfield, L. E., de Onis, M., Ezzati, M., ...Rivera, J. (2008).

Maternal and child undernutrition: Global and regional exposures and health consequences. Lancet, 371, $243-$ 60.

Harding J. (2004). Nutritional basis for the fetal origins of adult diseases (in) Fetal nutrition and adult disease: Programming of chronic disease through fetal exposure to undernutrition. Oxfordshire, UK: CABI Publishing.

Kanoa, B. J., Zabut, B. M., \& Hamed, A. T. (2011). Nutritnal status compared with nutritional history of preschool aged children in Gaza strip: Cross sectional study. Pakistan Journal of Nutrition, 10(3), 282-290.

Kyu, H. H., Georgiades, K., \& Boyle, M. H. (2009). Maternal smoking, biofuel smoke exposure and child height-for-age in seven developing countries. International Journal of Epidemiology, 38(5), 13421350.

Kyu, H. H., Shannon, H. S., Georgiades, K., \& Boyle, M. H. (2013). Association of urban slum residency with infant mortality and child stunting in low and middle income countries. BioMed Research International, 2013, 1-12. doi: http://dx.doi.org/10.1155/2013/604974

Picauly, I., \& Magdalena, S. (2013). Analisis determinan dan pengaruh stunting terhadap prestasi belajar anak sekolah di Kupang dan Sumba Timur, NTT. Jurnal Gizi dan Pangan, 8(1), 55-62.

Rahayu, L. S. (2011). Associated of health of parents with changes of stunting from 6-12 months to 3-4 years (Tesis). Yogyakarta: Universitas Gajah Mada. Retieved from

http://citeseerx.ist.psu.edu/messages/downloadsexceede d.html.

Republik Indonesia. (2012). Kerangka kebijakan gerakan sadar gizi dalam rangka seribu hari kehidupan (1000 HPK) versi 5 September 2012. Jakarta: Republik Indonesia

Republik Indonesia. (2013). Kerangka kebijakan gerakan sadar gizi dalam rangka seribu hari kehidupan (1000 HPK). Jakarta: Republik Indonesia

Ricci, K. A., Girosi, F., Tarr, P. I., Lim, Y. W., Mason, C., Miller, M., ... \& Guerrant, R. L. (2006). Reducing stunting among children: the potential contribution of diagnostics. Nature, 444(1), 29-38. 
Riskesdas. (2018). Evaluasi pelaksanaan tahun 2018 \& rencana tindak tahun 2019. Badan Penelitian dan Pengembangan Kesehatan, Kementerian Kesehatan RI

Riyadi, H., Martianto, D., Hastuti, D., \& Damayanthi, E., Murtilaksono, K. (2011). Faktor-faktor yang mempengaruhi status gizi anak balita di Kabupaten Timor Tengah Utara, Provinsi Nusa Tenggara Timur. Jurnal Gizi dan Pangan, 6(1), 66-73.

Scaling Up Nutrition. (2013). Country Progress in scaling up nutrition. Retrieved from http://scalingupnutrition.org/wpcontent/uploads/2013/02/SUN-Progress-January-201322_1-v2.pdf

Simbolon, D. (2012). Berat lahir dan kelangsungan hidup neonatal di Indonesia. Kesmas: National Public Health Journal, 7(1), 8-15. doi:

https://doi.org/10.21109/kesmas.v7i1.70.

United Nations Children's Fund (UNICEF). (2013). Improving child nutrition the achievable imperative for global progress. New York: United Nations Children's Fund. Retrieved from https://www.unicef.org/nutrition/index_68661.html.

World Health Organization (WHO). (2014). Global nutrition policy review: What does it take to scale up nutrition action. Geneva, Switzerland: WHO Press. 